Brit. F. Anaesth. (1972), 44, 175

\title{
PENTAZOCINE IN SEQUENTIAL ANALGESIC ANAESTHESIA
}

\begin{abstract}
K. RIFAT
SUMMARY

The technique of sequential analgesic anaesthesia, a new approach to balanced anaesthesia using fentanyl and pentazocine, is described. Elderly patients who were particularly at risk during orthopaedic surgery were studied and measurements made of blood pressure, pulse rate, central venous pressure, respiratory minute volume; arterial and venous $\mathrm{Po}_{2}, \mathrm{Pco}_{2}$ and $\mathrm{pH}$ were also measured. The results showed that good cardiovascular stability was achieved during the operation and in the postoperative period. Pentazocine reversed the respiratory depression produced by fentanyl and the patients were conscious and co-operative very soon after the operation. Excellent analgesia, on average lasting for 10 hours, was provided by the use of the two drugs. Side effects were infrequent and of no clinical importance. It was concluded that the technique of sequential analgesic anaesthesia was particularly useful for the elderly high-risk patients and that it could represent a valuable alternative anaesthetic technique for this group.
\end{abstract}

Analgesia plays a major role in modern anaesthetic practice and the discovery of more potent analgesics has allowed their increased use as a part of overall balanced anaesthesia aimed at producing better patient protection and limiting the neuro-autonomic activity of major surgery (Du Cailar, 1960; Gemperle, Moret and Megevand, 1966). In 1959 De Castro and Mundeleer devised the technique of neuroleptanalgesia (NLA) as a means of achieving this end and their original method has been widely used, employing a number of different analgesic agents.

In a recent review of neuroleptanalgesia, Brown (1969) pointed out the major advantages of the technique in providing excellent background sedation and analgesia, but admitted that the major disadvantage was the respiratory depression, or even apnoea, that may result from too large a dose of the morphine like analgesic. The discovery of the benzomorphan pentazocine, a potent analgesic with morphine antagonist properties, led De Castro and Viars (1968) to propose a modification of the original NLA which they called "anesthésie analgésique séquentielle" (AAS). With this technique several doses of a short-acting analgesic, fentanyl (Sublimaze), were given throughout the operation so that the patient remained completely free of pain. At the end of the surgical procedure the respiratory depressant effects of fentanyl were reversed by the injection of a fairly large dose of pentazocine (Fortral) which provided further analgesia through the early postoperative period. In our hospital the AAS technique has been modified by reducing the dose of fentanyl and pentazocine as compared with those used by De Castro and Viars and we have added nitrous oxide to the oxygen given during the operation. This paper describes the use of AAS in patients undergoing orthopaedic surgery: concurrently with this study the cardiovascular pharmacodynamics of fentanyl and pentazocine were investigated in dogs and these results have already been reported (Rifat, Moret and Gemperle, 1971).

\section{PATIENTS AND METHOD}

Fifty-two patients in the age range $65-92$ years were studied. Apart from the chronic changes seen in old age all the patients were fit and all received intensive respiratory physiotherapy before admission. The orthopaedic surgery was confined to the hip joint and involved either a total hip prosthesis, prosthetic replacement of the femoral head or osteosynthesis of the neck of the femur.

One hour before the operation the patients were given preanaesthetic medication of $0.5 \mathrm{ml}$ Thalamonal (fentanyl $0.025 \mathrm{mg}$ and droperidol $1.25 \mathrm{mg}$ ) and atropine $0.25-0.5 \mathrm{mg}$ by intramuscular injection. Before the induction of anaesthesia control measurements of blood pressure, pulse rate, respiratory

K. RIFAT, M.D., Institute of Anaesthesiology, University Hospital, Hopital Cantonal, Geneva, Switzerland. 
minute volume and blood-gas analyses were made. A continuous glucose infusion was given through the catheter placed in the superior vena cava (see measurements: section (f)). Anaesthesia was induced with propanidid (Epontol) 50-150 mg given intravenously, and the patients were intubated after the administration of suxamethonium (Celocurine) 25-50 mg. Immediately after this the analgesic anaesthesia was started with an initial intravenous injection of fentanyl $0.025 \mathrm{mg} / \mathrm{kg}$ body weight. Muscle relaxation was obtained with alcuronium (Alloferin) in a dose of $0.2 \mathrm{mg} / \mathrm{kg}$ body weight and the patients were ventilated by an Engström ventilator using a mixture of 50 per cent oxygen and 50 per cent nitrous oxide at the rate of 16 b.p.m. This was approximately 15 per cent greater than the spontaneous respiratory rate before surgery.

During the operation analgesia was maintained by intravenous injections of fentanyl $0.125 \mathrm{mg}$, given at the first sign of increasing blood pressure, pulse rate or facial muscle twitch. Any blood loss was replaced by the same volume of whole blood. The nitrous oxide was stopped about 5 minutes before the end of surgery and the muscle relaxation reversed by the intravenous injection of atropine $0.5 \mathrm{mg}$ and neostigmine $2.5 \mathrm{mg}$. The patient was then allowed a full minute to see if there was a spontaneous resumption of respiration. If respiration did not restart spontaneously the patient was ventilated and intravenous pentazocine given in a dose of $1 \mathrm{mg} / \mathrm{kg}$ (the average dose was pentazocine $60 \mathrm{mg}$ ). As soon as the patient was awake and breathing spontaneously measurements of blood pressure, pulse rate, central venous pressure and blood-gas analyses were made. The patients were transferred to a recovery room for the next 4 hours during which time they received oxygen $2 \mathrm{l} . / \mathrm{min}$ through a nasal tube.

\section{MEASUREMENTS}

The following measurements were made before the induction of anaesthesia, during the operation and for 4 hours in the recovery room:

(a) Minute volume, using the Wright spirometer mounted on a close fitting facemask which made an airtight fit over the nose and mouth of the patient.

(b) Respiratory rate/minute.

(c) Arterial and venous $\mathrm{Po}_{2}, \mathrm{Pco}_{2}$ and $\mathrm{pH}$ with heparinized blood samples taken from the radial artery and the superior vena cava. $\mathrm{pH}$ measurements were made with the Radiometer pH meter PHM-27, and blood-gas measurements were made with the Radiometer electrodes. (d) Pulse rate was measured from a continuous e.c.g. recording.

(e) Systolic and diastolic blood pressures were measured by auscultation.

(f) Central venous pressure was measured from the superior vena cava using a catheter inserted through the subclavian vein.

(g) In some patients continuous e.e.g. records were made.

All these measurements were made by the author and the blood-gas analyses were performed by the same technician. At the end of the operation the first measurements were made approximately 15 minutes after the injection of pentazocine and these were repeated at hourly intervals for 4 hours.

\section{RESULTS}

After the operation, when the muscle relaxation had been reversed and the nitrous oxide stopped, 48 of the patients were unconscious, and did not respond to stimuli : $60-90 \mathrm{sec}$ after the mechanical ventilation had ceased spontaneous respiration was either absent or inadequate. Immediately after the intravenous injection of pentazocine ( $1 \mathrm{mg} / \mathrm{kg}$ body weight) spontaneous respiration restarted, the minute volume exceeded the preanaesthetic value (fig. 1) and the patient regained consciousness. The endotracheal tube was removed at this point. The respiratory rate showed a similar change (fig. 2) but the pattern of respiration was not significantly different from the preanaesthetic pattern, and over the 4 hours of the study all patients maintained adequate spontaneous ventilation.

\section{Blood-gas analysis.}

Figures 3-7 show the changes recorded in the arterial and venous $\mathrm{Po}_{2}, \mathrm{Pco}_{2}$ and $\mathrm{pH}$. The relatively low $\mathrm{Pa}_{0_{2}}$ (mean $86 \mathrm{~mm} \mathrm{Hg}$ ) recorded before operation (fig. 3) was probably normal for patients in this age group who would have a degree of chronic bronchitis, emphysema and respiratory insufficiency. During the operation the mean $\mathrm{Pa}_{\mathrm{O}}$ values were considerably raised as a result of the high oxygen concentration in the anaesthetic gas mixture. After the operation, when the patients were spontaneously breathing room air, the $\mathrm{Pa}_{\mathrm{O}_{2}}$ value was the same as that preoperatively, but when the patients were moved to the recovery room and given oxygen at $2 \mathrm{l} . / \mathrm{min}$ the mean $\mathrm{Pa}_{\mathrm{O} 2}$ rose to almost $100 \mathrm{~mm} \mathrm{Hg}$. The changes in mean venous $\mathrm{Po}_{2}$ were insignificant and remained within normal limits during the period of the study (fig. 4). 


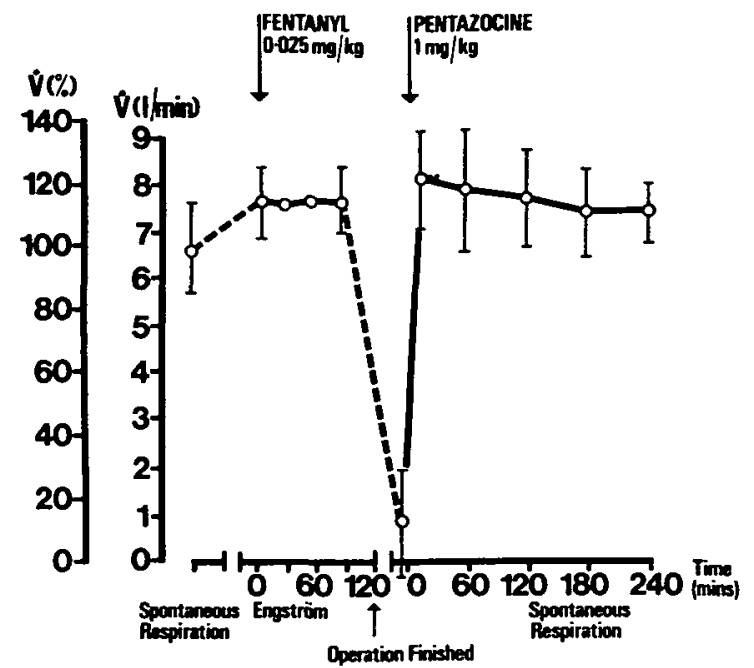

FIG. 1. Mean changes in minute volume ( $\pm 1 \mathrm{SD})$; $n=37$.

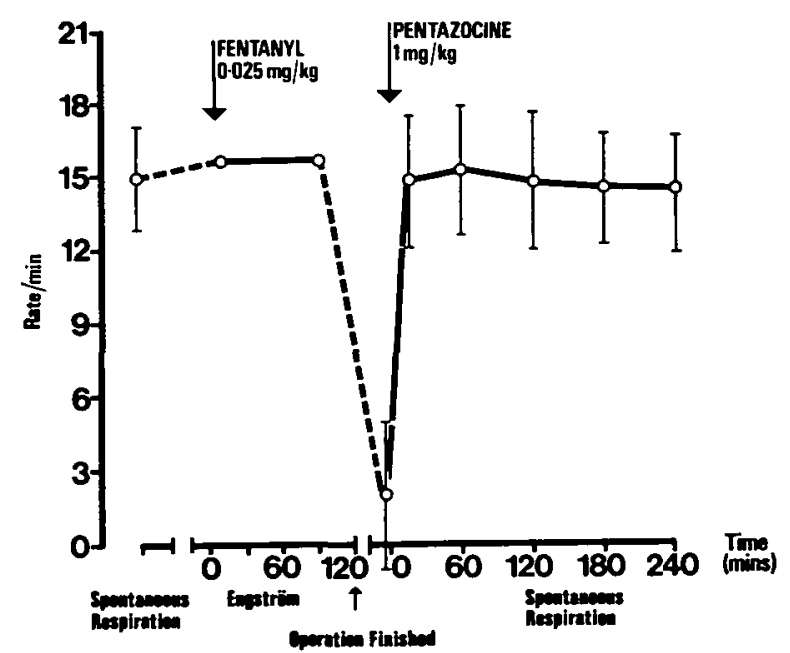

FIG. 2. Mean change in respiratory rate ( $\pm 1 \mathrm{SD}) ; n=37$.

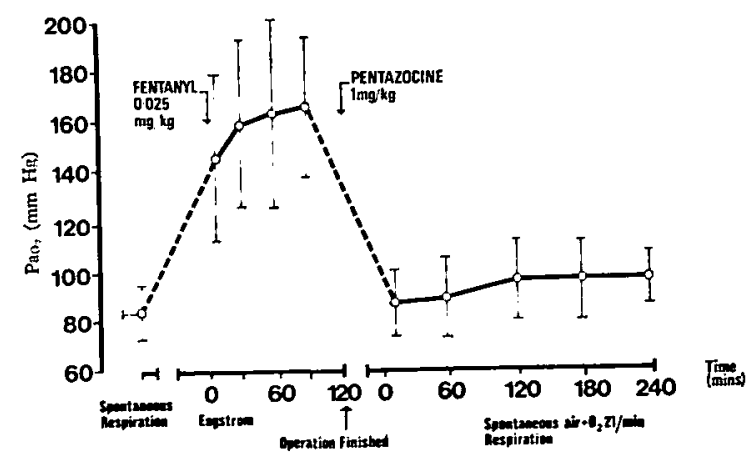

FIG. 3. Mean changes in arterial $\mathrm{Po}_{2}(+1 \mathrm{SD}) ; n=34$. During the period of mechanical ventilation the patients were breathing 50 per cent oxygen +50 per cent nitrous oxide.

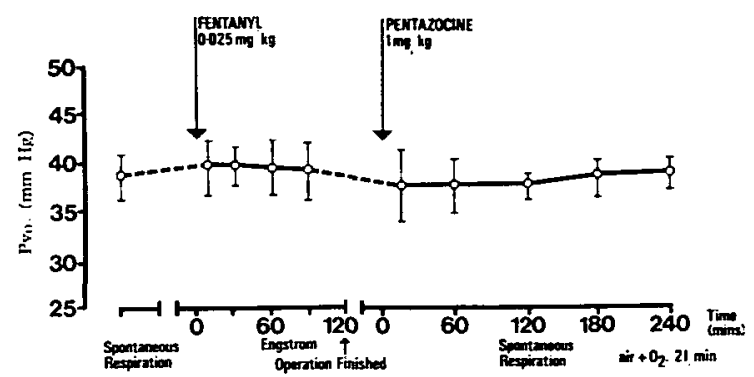

FIG. 4. Mean change in venous $\mathrm{Po}_{2}( \pm 1 \mathrm{SD}) ; n=27$. During the period of mechanical ventilation the patients were breathing 50 per cent oxygen +50 per cent nitrous oxide.

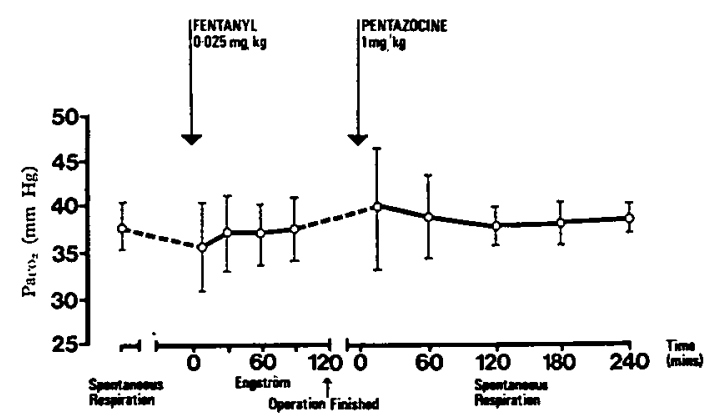

FIG. 5. Mean change in $\mathrm{PacO}_{2}( \pm 1 \mathrm{SD}) ; n=33$.

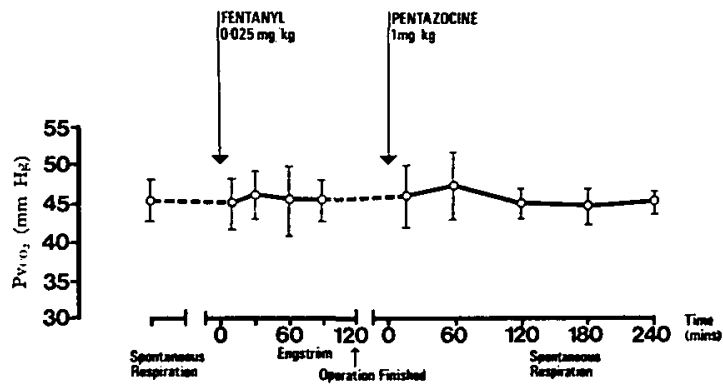

FIG. 6. Mean change in $\mathrm{PvCO}_{2}( \pm 1$ SD); $n=26$.

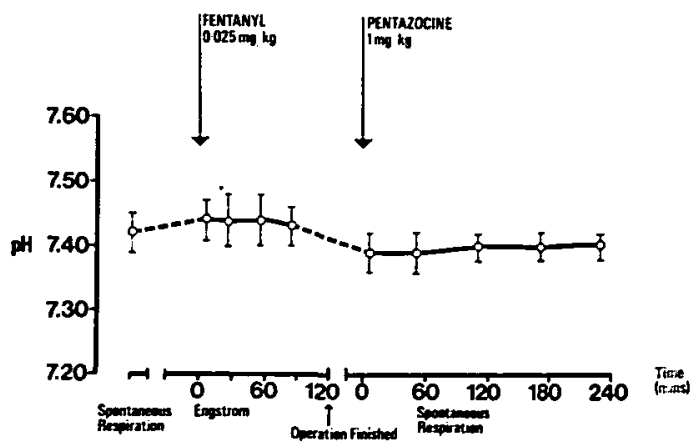

Fig. 7. Mean change in $\mathrm{pH}( \pm 1 \mathrm{SD})$. 
The changes in $\mathrm{PCO}_{2}$ (figs. 5 and 6) were also minor, confirming that the patients were not hyperventilated during the operation. The first measurements after the end of surgery, when the patients had just resumed spontaneous breathing were slightly elevated, but the $\mathrm{Pa}_{\mathrm{CO}_{2}}$ and $\mathrm{Pv}_{\mathrm{OO}_{2}}$ rapidly returned to the preoperative values. There were no significant changes in arterial $\mathrm{pH}$ (fig. 7) the mild postoperative acidosis probably being caused by factors other than drug administration.

\section{Blood pressure measurements.}

Approximately $10 \mathrm{~min}$ after the initial injection of fentanyl both systolic and diastolic arterial pressure fell by 15-20 per cent as compared with the control values measured before operation (figs. 8-9). The mean systolic pressure fell from 145 to $112 \mathrm{~mm} \mathrm{Hg}$ and the mean diastolic pressure from 83 to $72 \mathrm{~mm}$ $\mathrm{Hg}$. Despite this fall the skin remained warm and

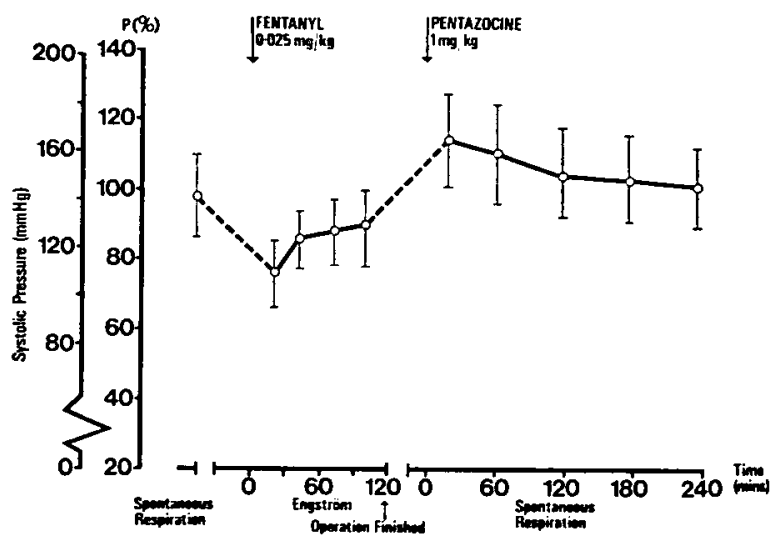

FIG. 8. Mean changes in systolic pressure ( \pm 1 SD);

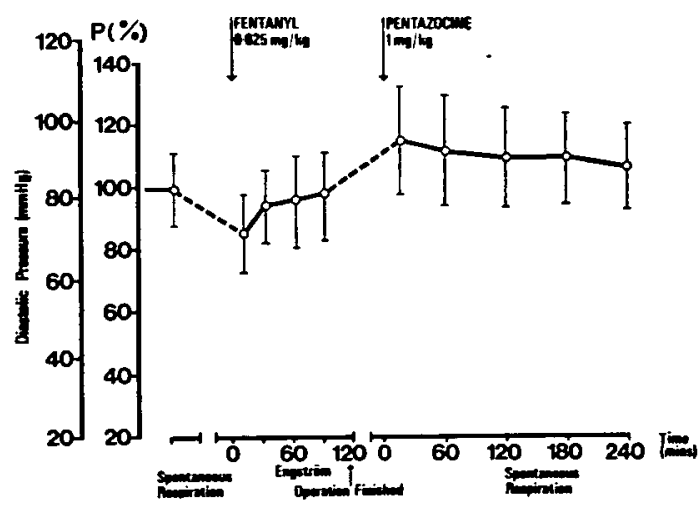

FIG. 9. Mean changes in diastolic pressure ( $\pm 1 \mathrm{SD}$ ); $n=46$. pink throughout the operation. At this point the accelerated infusion of $300-500 \mathrm{ml}$ of glucose solution produced a slight increase in both systolic and diastolic pressure and the subsequent injections of fentanyl had no further effect on the bloood pressure. After the injection of pentazocine there was an increase of both systolic and diastolic pressure to a mean value of $15-20$ per cent above the control value, which then gradually returned to the preoperative level over the next 4 hours.

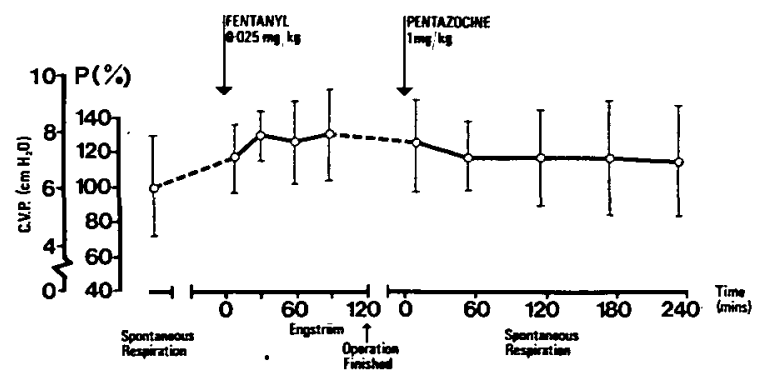

Fig. 10. Mean changes in central venous pressure $( \pm 1 \mathrm{SD}) ; n=34$.

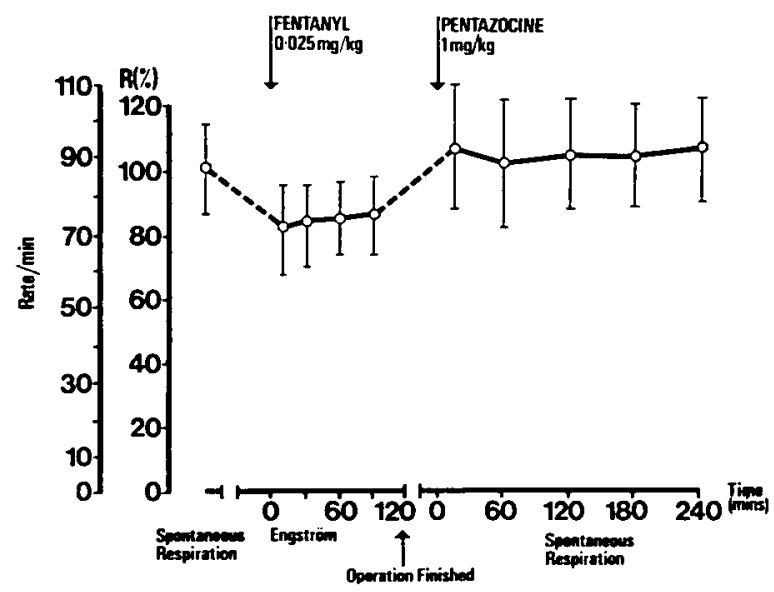

FIG. 11. Mean changes in heart rate $( \pm 1$ SD); $n=45$.

Changes in central venous pressure (fig. 10) were minimal, and the slight rise seen at the start of the operation was probably a result of the mechanical ventilation at a mean endotracheal pressure of 3-4 $\mathrm{cm} \mathrm{H}_{2} \mathrm{O}$. The changes in heart rate are shown in figure 11. After the injection of fentanyl there was a sinus bradycardia, the mean rate falling from 88 to 71 beats/min or by 20 per cent compared to the control value. This persisted, without increasing, after further injections of fentanyl. Immediately after the injection of pentazocine there was a tachycardia 
which was approximately 25 per cent above the mean heart rate recorded at the end of the operation (74 to 93 beats/min). This tachycardia persisted and was responsible in two patients for e.c.g. changes indicative of myocardial ischaemia which responded to intravenous digitalization and oxygen therapy.

\section{E.e.g. measurements.}

It was possible to monitor the e.e.g. in six patients all of whom showed a similar pattern. Within $90 \mathrm{sec}$ of the injection of fentanyl the trace showed a typical phase 2 sleep curve with bilateral spindles. During the operation there were certain fluctuations with a lack of spindles and the appearance of $K$ complexes -that is, a type 3 sleep pattern. After the injection of pentazocine the trace changed to a normal conscious trace as the patient awakened, but, if the patient was left without external stimulation the e.e.g. trace showed fluctuations which indicated physiological sleep; at no time was there any epileptiform activity. A series of typical traces obtained from a male patient is shown in figure 12 .
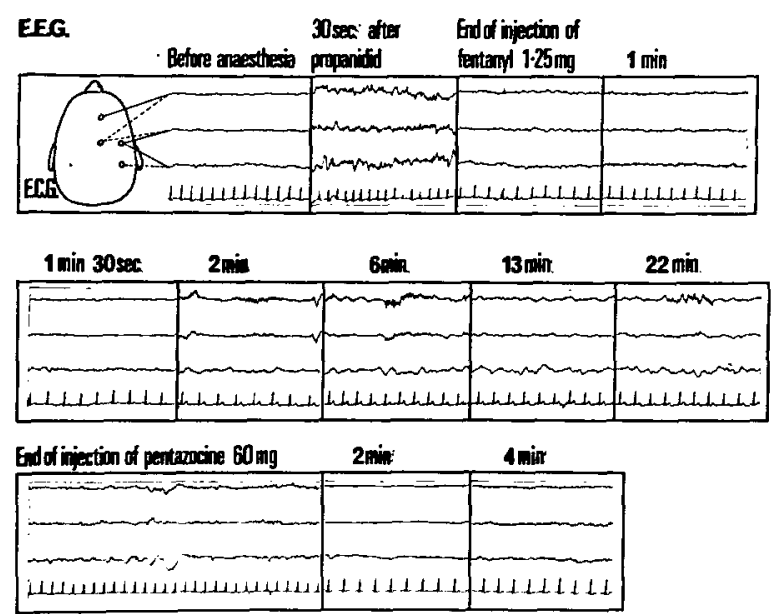

FIG. 12. Electroencephalogram trace from a male patient. On the night before surgery the patient received nitrazepam $5 \mathrm{mg}$ and diazepam $10 \mathrm{mg}$. Pre-anaesthetic medication on the day of surgery was atropine $0.5 \mathrm{mg}$ and pethidine $50 \mathrm{mg}$. Two minutes after the injection of pentazocine the trace pattern has reverted to normal compared with the trace before anaesthesia.

General condition of the patients.

During the time in the recovery room the patients were calm, indifferent to their surroundings and slightly drowsy, yet all were capable of answering questions, obeying commands and could drink normally. Analgesia in all instances was excellent: further injections of analgesics were given only when the patients themselves complained of their pain and requested relief. For three patients this occurred within 5 hours of the end of the operation. However, ten patients made no complaint or request within the first 20 hours of the operation and for the group of 52 patients the mean duration between the end of the operation and the first complaint of pain was approximately 10 hours. Five patients were noted to be perspiring profusely after operation and one patient had a pyrexia of $39^{\circ} \mathrm{C}\left(102.2^{\circ} \mathrm{F}\right)$. Approximately 10 per cent of the patients were shivering and had peripheral vasoconstriction during their stay in the recovery room, but the administration of droperidol $2.5 \mathrm{mg}$ improved their condition and stopped the shivering. There were no complications involving the muscle relaxants or their reversal.

During the operation the mean hourly urine output was $54 \mathrm{ml} /$ hour. Two patients developed postoperative urinary retention, and four patients had mild nausea and vomiting in the first 15 hours after the operation. There were no other complications and no deaths occurred as a result of the anaesthetic technique.

\section{DISCUSSION}

From these results it would seem that analgesic anaesthesia using fentanyl is a useful technique and that the additional use of pentazocine makes it possible to avoid the undesirable side effects seen with fentanyl at the end of the operation and also provides good analgesia for a prolonged period of time. Elderly patients were deliberately studied because this group are particularly at risk during surgery and may have exaggerated pharmacodynamic responses to drugs (Rifat, 1970). Operations on the hip are known to be painful and stressful, requiring fairly powerful analgesia: patients in this category were therefore particularly suitable for investigation and in addition there was no direct cardiovascular or respiratory interference with this type of operation.

The outstanding feature of the technique of sequential analgesic anaesthesia is the absence of clinically important effects on the cardiovascular system. Fentanyl, like all morphine derivatives, will produce depression of the cardiovascular system (Bouyard, 1968; Roquebert et al., 1968; Tammisto, Takki and Toika, 1970) although Gemperle and Moret (1968) showed that, provided care is taken to compensate for the relative hypovolaemia due to the reduction in peripheral resistance, the usual clinical doses of fentanyl used in NLA have no effect on the 
cardiovascular system. Grell, Koons and Denson (1970) found that fentanyl produced only minimal depression of the cardiovascular system but that larger doses produced respiratory depression of the Cheyne-Stokes type, leading to apnoea and loss of consciousness. The respiratory depression produced by fentanyl has also been shown to be related to the dose and route of administration by De Castro and Viars (1968), Roquebert and associates (1968) and Dobkin, Lee and Byles (1965).

The present study, together with that in dogs (Rifat, Moret and Gemperle, 1971) showed that fentanyl had no clinically important effect on the blood pressure. In dogs there was a decrease in peripheral resistance associated with vasodilatation and a relative hypovolaemia, which were corrected by increasing the blood volume. The sinus bradycardia produced by fentanyl was probably a cholinergic effect and was partially reversible with atropine as was shown by Bouyard (1968), and Roquebert and associates (1968). The sedation and respiratory depression produced by fentanyl was obviously severe and at the end of the operation only a few of the patients were breathing spontaneously and very few showed signs of waking.

Some authors claim that the cardiovascular effects of pentazocine are similar to, but less pronounced than, those of the morphine derivatives (Ahlgren and Stephen, 1966; Poisvert et al., 1969; Stephen, Davie and Scott, 1970) while other workers have demonstrated a positive inotropic effect (Lal, Savidge and Chhabra, 1969; Scott and Orr, 1969; Scott and Adgey, 1971). In dogs we have demonstrated a positive inotropic action (Rifat, Moret and Gemperle, 1971) which has been confirmed by Levitsky and others (1971). It was suggested by Kay, Keaney and Taylor (1970) that pentazocine stimulated the alphareceptors and they showed that this effect was blocked by droperidol. The tachycardia seen after the injection of pentazocine is a common finding and usually transient (Scott and Adgey, 1971; Tammisto, Takki and Toika, 1970; Stephen, Davie and Scott, 1970) so the finding in this study that it persisted throughout the investigation suggested a possible dose-related effect. The respiratory depression produced by pentazocine is due mainly to a decrease in respiratory rate (Ahlgren and Stephen, 1966) and is less pronounced and of much shorter duration than that produced by the morphine derivatives (Kay, Keaney and Taylor, 1970; Jennett, Barker and Forrest, 1968; Dyrberg, Jenningsen and Johansen, 1967). Furthermore, successive doses of pentazocine do not produce cumulative respiratory depression (Davie, Scott and Stephen, 1970). The lack of change in the central venous pressure (c.v.p.) measurements was surprising in view of the findings of Scott and Adgey (1971) and Stephen, Davie and Scott (1970) who showed that pentazocine and the morphine-like drugs produced an increase in the central venous pressure.

The observation that pentazocine antagonized the undesirable effects of fentanyl was not surprising because it has been shown that pentazocine is a weak morphine antagonist (Hunter, 1968; Keats and Telford, 1964) and Davie, Stephen and Scott (1971) also showed that pentazocine antagonized the respiratory depressant effects of pethidine. The excellent analgesia was also to be anticipated because Hamilton and associates (1967) found that, unlike nalorphine, pentazocine appeared to augment the analgesic effects of pethidine. The duration of postoperative analgesia which was found in the present study was greatly in excess of that found after single doses of fentanyl or pentazocine given alone and this must be considered as a further advantage for the technique. The e.e.g. changes showed that pentazocine reversed the hypnotic effect of fentanyl, a finding also reported by Haas, Kubicki and Stolzel (1971).

In conclusion, this study showed that in elderly, high-risk patients, the technique of sequential analgesic anaesthesia with fentanyl and pentazocine offered many advantages. Cardiovascular stability during the operation and in the postoperative period was good, and respiratory depression was not a problem once the depressant effects of fentanyl had been reversed by pentazocine. The sleep pattern induced by fentanyl was also reversed by the use of pentazocine to produce a trace very similar to physiological sleep. In the postoperative period the patients were conscious and co-operative yet remained free of pain for up to 10 hours after the injection of pentazocine. Side effects were rare and caused no difficulty, even the incidence of postoperative shivering being about the same as that seen with other anaesthetic techniques: urinary output was good during the operation and throughout the period of the study. Thus the technique of sequential analgesic anaesthesia in which potent analgesics can be used to supplement light general anaesthesia, might become the preferred technique for patients who present a high operative risk, offering good cardiovascular and respiratory stability combined with good analgesia and freedom from side effects. 


\section{ACKNOWLEDGEMENTS}

I wish to express my thanks to Professor M. Gemperle, Director of the Institute of Anaesthesiology, for his help with this study. Also to Miss A. Bischof for her general assistance and Miss E. Koch for performing the blood-gas analyses.

\section{REFERENCES}

Ahlgren, E. W., and Stephen, C. R. (1966). Laboratory and clinical experience with a new analgesic, pentazocine. Anesth. Analg. Curr. Res., 45, 678.

Bouyard, P. (1968). Effets cardiovasculaires des analgésiques morphiniques. Ann. Anesth. franc., 9, 329.

Brown, A. S. (1969). Neuroleptanalgesia; in Newer Intravenous Anesthetics, vol. 7 (ed. R. S. J. Clarke), p. 159. Boston: Little, Brown \& Co.

Davie, I., Scott, D. B., and Stephen, G. W. (1970). Respiratory effects of pentazocine and pethidine in patients anaesthetized with halothane and oxygen. Brit. f. Anaesth., 42, 113 .

Davie, I. T., Stephen, G. W., and Scott, D. B. (1971). The effects of premedication with pentazocine and pethidine on respiration during general anaesthesia. Brit. F. Anaesth., 43, 500.

De Castro, G., and Mundeleer, P. (1959). Anesthésie sans barbiturates: la neuroleptanalgesie. Anesth. et Analg., 16, 1022.

De Castro, J., and Viars, P. (1968). Anesthésie analgésique séquentielle on A.A.S. Ars Med., 23, 121.

Dobkin, A. B., Lee, P. K. Y.. and Byles, P. H. (1965). Neuroleptanalgesics. 2: Laboratory evaluation of combination of analgesics and neuroleptics with nitrous oxide. Canad. Anaesth. Soc. F., 12, 39.

Du Cailar, J. (1960). Place de l'analgésie dans l'anesthésie générale. Agressologie, 1, 5.

Dyrberg, V., Henningsen, P., and Johansen, S. H. (1967). The respiratory effects of pentazocine. Acta anaesth. scand., 11, 77.

Gemperle, M., and Moret, P. (1968). Influence du fentanyl sur la system cardiovasculaire. Ann. Anesth. franc., 9, 333.

- Megerand, R. (1966). Neuroleptanalgesie et système cardiovasculaire. Ann. Anesth. franc. spec., $1,87$.

Grell, F. L., Koons, R. A., and Denson, J. S. (1970). Fentanyl in anesthesia: a report of 500 cases. Anesth. Analg. Curr. Res., 49, 523.

Haas, J., Kubicki, St., and Stolzel, R. (1971). Der Fentanylantagonistische Effeckt des Pentazocin in EEG, ENG und evozierten kortikalen Potentialen. I. EEG-EMG., $2,46$.

Hamilton, R. C., Dundee, J. W., Clarke, R. S. J., Loan, W. B., and Morrison, J. D. (1967). Alterations in response to somatic pain associated with anaesthesia. XVIII: Studies with some opiate antagonists. Brit. $\mathcal{f}$. Anaesth., 39, 490.

Hunter, A. R. (1968). The respiratory effects of pentazocine in rabbits. Anaesthesia, 23, 238.

Jennett, S., Barker, J., and Forrest, J. B. (1968). A doubleblind controlled study of the effects on respiration of pentazocine, phenoperidine and morphine in normal man. Brit. f. Anaesth., 40, 864.

Kay, B., Keaney, J. P. D., and Taylor, G. J. (1970). Neuroleptanalgesia: a double-blind comparison of pentazocine and phenoperidine for neuroradiological investigations. Brit. F. Anaesth., 42, 329.

Keats, A. S., and Telford, J. (1964). Studies of analgesic drugs. VIII: A narcotic antagonist analgesic without psychotomimetic effects. F. Pharmacol. exp. Ther., 143, 157.
Lal, S., Savidge, R. S., and Chhabra, G. P. (1969). Cardiovascular and respiratory effects of morphine and pentazocine in patients with myocardial infarction. Lancet, 1, 379.

Levitsky, S., Mullin, E. M., Sloane, R. E., and Morrow, A. G. (1971). Experimental evaluation of pentazocine: effect on myocardial contractility and peripheral vascular resistance. Amer. Heart $\mathfrak{F}$., 81, 381 .

Poisvert, M., Debras, C., Galinski, R., and Millet, D. (1969). Notre expérience de l'utilisation de la pentazocine en association pour l'anesthésie prolongée, l'anesthésie brève et l'anesthésie chez l'adulte et l'enfant. Ann. Anesth. franc., 10, 613.

Rifat, K. (1970). L'anesthésie-réanimation chez le vieillard en traumatologie. Praxis, 59, 49.

_ Moret, P., and Gemperle, M. (1971). Les effets de l'anesthésie analgésique séquentielle sur le système cardio-vasculaire du chien (étude expérimentale). Ann. Anesth. franç., 12, 1.

Roquebert, J., Courtois, P., Dumartin, A., Canellas, J. and Sabathié, M. (1968). De l'influence des neuroleptiques sur les effets secondaires des analgésiques (étude expérimentale). Ann. Anesth. franç., 9, 321.

Scott, M. E., and Adgey, A. A. J. (1971). Circulatory effects of intravenous pentazocine in patients with acute myocardial infarction. Curr. ther. Res., 13, 81.

- Orr, R. (1969). Effects of diamorphine, methadone, morphine and pentazocine in patients with suspected acute myocardial infarction. Lancet, 1, 1065.

Stephen, G. W., Davie, I., and Scott, D. B. (1970). Circulatory effects of pentazocine and pethidine during general anaesthesia with nitrous oxide, oxygen and halothane. Brit. f. Anaesth., 42, 311.

Tammisto, T., Takki, S., and Toikka, P. (1970). A comparison of the circulatory effects in man of the analgesics fentanyl, pentazocine and pethidine. Brit. $\mathcal{F}$. Anaesth., 42, 317.

\section{LA PENTAZOCINE DANS L'ANESTHESIE ANALGESIQUE SEQUENTIELLE}

\section{SOMMAIRE}

La technique d'anesthésie analgésique séquentielle, qui constitue un nouveau mode d'approche de l'anesthésie balancée faisant appel au fentanyl et à la pentazocine, est ici décrite. Cette étude a porté sur des malades âgés qui étaient exposés à un risque particulièrement évident au cours d'interventions de chirurgie orthopédique. Les paramètres suivants ont été mesurés: pression artérielle, fréquence cardiaque, pression veineuse centrale, débit respiratoire minute, ainsi que tensions artérielles et veineuses en oxygène $\mathrm{Po}_{2}$ et en gaz carbonique $\mathrm{Pco}_{2}$ et pH. Les résultats enregistrés indiquentqu' une stabilité cardiovasculaire satisfaisante a été obtenue au cours de l'intervention et de la période post-opératoire. La pentazocine a exercé un effet antagoniste vis-à-vis de la dépression respiratoire induite par le fentanyl et les malades ont été conscients et coopératifs très tôt après l'opération. L'emploi des deux médications a permis de parvenir à une excellente analgésie ayant persisté, en moyenne, pendant dix heures. Des effets secondaires n'ont pas été fréquemment notés et ils furent en tous cas sans importance clinique. On en a conclu que la technique d'anesthésie analgésique séquentielle était particulièrement utile chez les malades âgés présentant un risque opératoire certain et qu'elle pouvait représenter une alternative valable de technique anesthésique pour cette catégorie d'opérés. 


\section{PENTAZOCINE IN \\ SEQUENZ-NEUROLEPTANALGESIE}

\section{ZUSAMMENFASSUNG}

Es wird zunächst die Technik der Sequenz-Neuroleptanalgesie, einer neuen Methode der balancierten Anaesthesie mit Fentanyl und Pentazocine, beschrieben. Es wurden ältere Patienten untersucht, die anläßlich orthopädischer Operationen ein besonders hohes Risiko eingingen. Gemessen wurden der Blutdruck, die Herzfrequenz, der zentrale Venendruck, das respiratorische Minutenvolumen: Arterieller und venöser $\mathrm{Po}_{2}, \mathrm{PcO}_{2}$ und $\mathrm{pH}$ wurden ebenfalls gemessen. Die Ergebnisse zeigten gute und stabile Kreislaufverhältnisse während der Operation und in der postoperativen Phase. Pentazocine dämmte die durch Fentanyl hervorgerufene Atemdepression ein, und die Patienten kamen bald nach der Operation zu Bewußtsein und Kooperation. Die hervorragende Analgesie, die durch die Verwendung der beiden Präparate erreicht wurde, hielt im Durchschnitt über zehn Stunden an. Nebenwirkungen waren selten und klinisch unwesentlich. Man kann den Schluß ziehen, daß die Methode der SequenzNeuroleptanaigesie besonders nützlich für Operationen an älteren Patienten ist und eine wertvolle Alternativlösung zur Anaesthesie dieser Patientengruppe darstellt.

\section{PENTAZOCINA EN LA ANESTESIA ANALGESICA SECUENCIAL}

\section{RESUMEN}

Es descrita la técnica de anestesia analgésica secuencial, un nuevo procedimiento para una anestesia equilibrada utilizando fentanil y pentazocina. Fueron estudiados pacientes ancianos que presentaban un riesgo especial durante la cirugía ortopédica y fueron efectuadas mediciones de la presión arterial, frecuencia del pulso, presión venosa central, volumen minuto respiratorio; también fueron medidas la $\mathrm{Po}_{2}, \mathrm{PCO}_{2}$ y $\mathrm{pH}$ arteriales y venosos. Los resultados mostraron que se obtenía una buena estabilidad cardiovascular durante la operación y en el período posoperatorio. La pentazocina invirtió la depresión respiratoria producida por fentanil y los pacientes estaban conscientes y colaboraban muy pronto después de la operación. El uso de estos dos medicamentos dio una excelente analgesia con una duración media de diez horas. Los efectos secundarios fueron poco frecuentes y sin importancia clínica. Se concluyó que la técnica de anestesia analgésica secuencial era particularmente útil para los pacientes ancianos de riesgo elevado y que podía representar una valiosa ténica anestésica alternativa en este grupo de pacientes.

\section{BOOK REVIEWS}

Applied Cardiovascular Physiology. By G. R. Kelman. Published by Butterworths, London. Pp. 266; illustrated; indexed. Price $£ 6$.

Professor Kelman is one of a distinguished band of scientists who have chosen anaesthesia as a clinical camp and greatly enrich it by their research, teaching and writing. This book stems from his interest in the cardiovascular effects of anaesthetics and anaesthesia and reflects some of his own important studies in Leeds and Aberdeen. It is intended as a companion volume to Dr J. F. Nunn's Applied Respiratory Physiology.

In spite of its title, more than half of the book comprises almost pure physiology of the heart, peripheral circulation and tissue perfusion; indeed, the opening chapter is devoted to some rather hard-going physics which, fortunately, is not essential to an understanding of the remainder of the book. The chapter on the heart is specially useful and contains well presented information on the fashionable, if controversial, matter of myocardial contractility. A chapter on the control of the cardiac output employs many of Professor Guyton's teaching concepts which will be familiar to readers of the American literature. That section, in particular, would make profitable reading for all aspirants to practice in the intensive care unit. Throughout the early chapters, there is considerable emphasis on methods of measurement.

If there is a weak point, it is perhaps in the chapter on the effects of anaesthesia on the circulation. There exists a vast body of data on this subject and Professor Kelman has done a lot of sifting. However, the reader is still left with a catalogue of facts where authoritative comment would have been both possible and justified. By contrast, the chapter on shock is both clear and confident.

This book is warmly recommended for the departmental library and I would assume it to be of value outside the specialty of anaesthesia. The student of the basic sciences would do well to read it systematically. The more mature will find it a useful source of reference.

Alastair A. Spence
Hormones and Resistance. By $\mathrm{H}$. Selye. Springer-Verlag (1971). Pp. 1140; 37 fig. XVIII, VII. Price DM $268.00 ;$ ca. US $\$ 77.40$.

Selye has acquired a well-deserved reputation for immense industry in collecting the world literature on the endocrine changes in "stress", and this reputation will be further enhanced by this large new book. By the systematic use of abbreviations and tables, and by a rather telegraphic style of writing, he has compressed an astonishing amount of information into the book. Concentrated summaries of the literature on each point are connected by a few rather more discursive paragraphs giving a general view of the subject.

Most of the book deals with experiments on laboratory animals, and clinical studies are comparatively unemphasized, though the balance is partially maintained by some sections on clinical implications. The complex interactions between the endocrine system and many toxins, drugs and traumatic or metabolic disorders are fully documented; information on anaesthetic agents and respiratory disorders is given in many sections. Particular emphasis is laid on the use of steroids in preventing damage caused by physical or chemical agents. There is less attempt in this book than in some of Selye's previous works to collate the data from many fields to support a particular hypothesis; this abence of a central theme makes the book less readable as a whole but makes it perhaps more useful as an annotated and fully classified bibliography on the inter-reactions of hormones and disease states.

An experimental worker planning an investigation of the action of hormones in almost any particular type of "stress" will shorten the initial stages of literature reviewing by using the very full index, of nearly 90 pages. The cost of the book will put it out of reach of small departmental libraries, but the larger medical libraries should possess a copy of this valuable reference book.

7. C. Davis 